\title{
BAYANIHAN AND BELONGING
}

Filipinos and Religion in Canada

Filipinos make up one of the largest immigrant groups in Canada and the majority continue to retain their Roman Catholic faith long after migrating. Drawing on archival and ethnographic research in Canada and the Philippines from 1880 to 2017, Bayanihan and Belonging examines the role of religion within Filipino Canadian communities, both past and present.

With her primary focus on Winnipeg, home to Canada's oldest and largest Filipino Canadian community, Alison R. Marshall documents the current church-based and domestic religious traditions of migrant Filipinos. Marshall explores the day-to-day celebrations of bayanihan, or communal spirit, in many places, from churches to home chapels, and in many forms, from festivals to healing rituals. In its vibrant portrait of Manitoba's Filipino population, Bayanihan and Belonging demonstrates how religious practice can fulfil not only a need for spiritual expression but also for community and belonging.

(Asian Canadian Studies)

ALISON R. MARShall is a professor in the Department of Religion at Brandon University. 
This page intentionally left blank 


\section{ALISON R. MARSHALL}

\section{Bayanihan and Belonging}

Filipinos and Religion in Canada 
(C) University of Toronto Press 2018

Toronto Buffalo London

www.utorontopress.com

Printed in Canada

ISBN 978-1-4875-0324-6 (cloth)

ISBN 978-1-4875-2250-6 (paper)

( $)$

Printed on acid-free, $100 \%$ post-consumer recycled paper with vegetable-based inks.

Asian Canadian Studies Series

\section{Library and Archives Canada Cataloguing in Publication}

Marshall, Alison R., author

Bayanihan and belonging : Filipinos and religion in Canada / Alison R. Marshall.

(Asian Canadian studies)

Includes bibliographical references and index.

ISBN 978-1-4875-0324-6 (hardcover). - ISBN 978-1-4875-2250-6 (softcover)

1. Filipino Canadians - Manitoba - Religion. 2. Filipino Canadians -

Religion. 3. Filipinos - Manitoba - Religion. 4. Filipinos - Canada-Religion.

5. Filipino Canadians - Manitoba - Social life and customs. 6. Filipino Canadians - Social life and customs. 7. Filipinos - Manitoba - Social life and customs. 8. Filipinos - Canada - Social life and customs. 9. Catholics Manitoba. 10. Catholics - Canada. I. Title. II. Series: Asian Canadian studies

University of Toronto Press acknowledges the financial assistance to its publishing program of the Canada Council for the Arts and the Ontario Arts Council, an agency of the Government of Ontario.

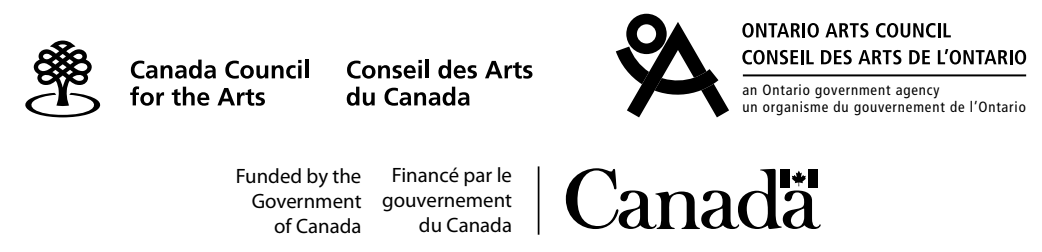

